\title{
IPTEK BAGI MASYARAKAT (IbM): IKAN MUJAIR KINTAMANI
}

\author{
I Wayan Widiana, I Made Satyawan, I Nyoman Dodik Prasetia \\ Universitas Pendidikan Ganesha
}

\begin{abstract}
ABSTRAK
Tujuan utama program iptek bagi masyarakat (IbM) ini adalah: (1) untuk meningkatkan wawasan dan pengetahuan anggota kelompok nelayan ikan kramba dalam mengemas produk ikan kramba, (2) untuk meningkatkan wawasan dan pengetahuan anggota kelompok nelayan ikan kramba dalam mengolah ikan kramba pasca panen, (3) untuk meningkatkan pendapatan dan kesejahteraan kelompok nelayan ikan kramba di Desa Abang Batu Dinding Kecamatan Kintamani. Sampai saat ini, pelatihan ini sudah dilaksanakan selama 2 bulan dilapangan atau $(70 \%)$ dari keseluruhan pelatihan. Pelatihan ini diikuti oleh 30 orang wanita dari desa Abang Batu Dinding Kintamani. Hasil yang dicapai selama ini (1) Tingkat partisipasi yang tinggi dari mitra program pengabdian kepada masyarakat memberikan dampak positif bagi pelaksanaan program, terlihat dari kehadiran peserta yang tanpa ijin, dan dukungan dari kepala desa. (2) Hasil pelatihan menunjukkan bahwa dari 30 orang yang ikut pelatihan 25 orang $(83,33 \%)$ masuk dalam kategori sangat mengetahui dan terampil dalam pengolahan produk ikan kramba pasca panen, 2 orang $(2,66)$ termasuk dalam kategori kategori mengetahui dan terampil dalam pengolahan produk ikan kramba pasca panen, dan 5 orang $(16,66)$ termasuk dalam kategori cukup mengetahui dan terampil dalam pengolahan produk ikan kramba pasca panen. (3) Hasil pelatihan menunjukkan bahwa dari 30 orang yang ikut pelatihan 20 orang $(66,67 \%)$ masuk dalam kategori sangat mengetahui dan terampil dalam mengembangkan IPTEK packing dan pengolahan pasca panen, $5(16,66)$ orang termasuk dalam kategori kategori mengetahui dan terampil dalam mengembangkan IPTEK packing dan pengolahan pasca panen, dan 5 orang $(16,66)$ termasuk dalam kategori cukup mengetahui dan terampil dalam mengembangkan IPTEK packing dan pengolahan pasca panen. Dan (4) Kendala pelaksanaan program adalah sulitnya meminid waktu untuk pencapaian kesepakatan pelaksanaan kegiatan, karena umumnya peserta latihan terbentur dengan rutinitas pekerjaan harian yang menunjang perekonomian keluarga, maupun pelaksanaan kegiatan ritual adat-istiadat yang lumayan padat di Desa Abang Batu Dinding Kintamani dalam kaitannya dengan paruman desa adat untuk penyelenggaraan ritual ada dan keagamaan.
\end{abstract}

\section{PENDAHULUAN}

Desa Abang Batu Dinding terletak pada ketinggian 867 sampai 1115 meter di atas permukaan air laut, dengan curah hujan rata-rata $1879 \mathrm{~mm} /$ tahun, dan suhu udara rata-rata $20 \mathrm{C}$ sampai $260 \mathrm{C}$, dengan luas wilayah Desa Abang Batu Dinding adalah $987 \mathrm{Ha}$, yang pemanfaatannya adalah Pemukiman umum: $52 \mathrm{Ha}$, Ladang/Kebun: 735,00 Ha, Hutan Lindung: 143,00 $\mathrm{Ha}$, Kuburan: 4,00 $\mathrm{Ha}$, dan Bangunan Umum: 15,00 Ha. Dengan julmlah penduduk 5.668 Jiwa atau $255 \mathrm{KK}$, yang terdiri dari Laki-laki: 2.227 Jiwa dan Perempuan: 3.141 Jiwa. Adapun batasbatas desa adalah sebagai berikut. Sebelah Utara : Desa Pingan, sebelah Selatan: Desa Kedisan, sebelah Barat: Desa Desa Batur dan Desa Kintamani, sebelah Timur: Danau Batur. Sementara orbitasi desa dengan pusat adalah: Ke lbu Kota Kecamatan Kintamani: $9 \mathrm{Km}$, Ke Ibu Kota Kabupaten Bangli: $25 \mathrm{Km}$, Ke lbu Kota Propinsi Bali: $78 \mathrm{Km}$. Mata pencaharian masyarakat Desa Abang Batu Dinding adalah $53 \%$ bermata pencaharian pertani, $17 \%$ nelayan, $9 \%$ pedagang, $2 \%$ Pegawai Negeri Sipil dan $2 \%$ pengerajin dan $14 \%$ buruh bangunan, 3\% lain-lain (Monografi Desa Abang Batu Dinding, 2012). Dari jumlah penduduk tersebut, $79,83 \%$ merupakan angkatan kerja produktif. Ini menunjukkan bahwa potensi sumberdaya manusia yang ada di Desa Abang Batu Dinding sangat menjanjikan. Namun, pendapatan masyarakat masih rendah (rata-rata pendapatan penduduk Rp. 457.000,-), padahal potensi yang dapat dikembangkan sangat banyak, seperti: pertanian, perikanan, peternakan, kerajinan/industri rumah tangga dan pariwista.

Pada sektor pertanian masyarakat Desa Abang Batu Dinding sangat terkenal dengan tanaman holtikulturanya. Jenis tanaman holtikultura yang dikembangkan di wilayah Desa Abang Batu Dinding adalah, cabe lombok, cabe bali, jagung, kentang, kubis, tomat, bawang merah dan bawang putih yang menjadi primadona serta aneka 
sayuran lainnya. Aneka tanaman ini dapat ditanam sepanjang musim, baik musim hujan maupun musim kering. Pada musim hujan tanaman holtikultura menghandalkan air hujan untuk tumbuh dan berkebang, sedangkan dimusim panas masyarakat Desa Abang Batu Dinding memanfaatkan air danau untuk mengairi tanamannya. Proses mengairi tanaman sayuran dilakukan dengan menggunakan mesin penyedot air dan selang untuk mengirim air ketanaman yang akan diairi. Walapun demikian tidak semua areal pertanian dapat terjangkau dengan air danau dimusim kemarau, sehingga hanya tanah-tanah disekitar danau saja yang dapat menanam tanaman holtikultura.

Selain sektor pertanian sektor utama penunjang kehidupan masyarakat Desa Abang Batu Dinding adalah sektor perikanan. Hal ini disebabkan karena wilayah Desa Abang Batu Dinding sebagian besar merupakan wilayah danau batur yang dapat dimanfaatkan untuk mengembangkan ikan air tawar. Pada awalnya masyarakat Desa Abang Batu Dinding, khususnya yang bergelut dalam bidang perikanan (ikan air tawar) atau nelayan hanya memanfaatkan ikan yang secara alami hidup dan berkembang di Danau Batur tanpa proses budidaya. Hasil tangkapan ikan dari Danau Batur pada awalnya sangat menggembirakan bahkan mampu memenuhi kebutuhan para nelayan untuk menyekolahkan anak-anak dan menghidupi rumah tangga. Namun seiring dengan semakin meningkatnya para nelayan dan kebutuhan ikan air tawar dari hari-kehari menyebabkan semakin menipisnya ikan yang hidup dan berkembang di Danau Batur. Bahkan ikan yang benar-benar siap untuk dipanen semakin hari semakin menipis, sehingga ikan yang sebenarnya belum siap untuk dipanen juga ditangkap oleh nelayan untuk dijual guna memenuhi kebutuhan hidup. Implikasinya ikan siap panen yang ada di Danau Batur tidak mampu memenuhi memenuhi permintaan pasar.

Salah satu usaha yang dilakukan oleh para nelayan di Desa Abang Batu Dinding Kintamani adalah dengan mengembangkan model pembudidayaan ikan air tawar dengan sistem kramba. Pembudidayaan ikan air tawar dengan sistem kramba membutuhkan modal yang sangat besar, mengingat bahan baku membuat kramba, biaya membuat kramba, benih ikan, pakan ikan dan biaya perawatan membutuhkan modal yang sangat besar. Pada awalnya hanya beberapa nelayan saja yang mempunyai kramba yaitu nelayan-nelayan yang memiliki modal. Kramba yang dibuatpun masih sangat kecil dengan kemampuan untuk membudidayakan ikan air tawar yang sangat terbatas. Berbagai persoalan terjadi berkaitan dengan pembudidayaan ikan kramba secara pribadi ini, khususnya berkaitan dengan modal usaha, pemeliharaan dan perawatan serta pembibitan. Bahkan beberapa kramba akhirnya tidak produktif karena proses pemeliharaan dan perawatan yang sangat menyulitkan. Akhirnya masyarakat Desa Abang Batu Dinding yang bergelut dalam bidang nelayan mengembangkan kelompok-kelompok nelayan yang membudidayakan ikan air tawar dengan sistem kramba. Ada beberapa keunggulan model pembudidayaan dengan sistem kramba ini, yaitu (1) ikan yang dipelihara dapat dikembangkan sesuai dengan keinginan dan kebutuhan, (2) cara pemeliharaan yang lebih mudah, karena terdapat dalam satu tempat, (3) masa panen dapat ditentukan sesuai dengan kebutuhan, (4) proses perawatan lebih mudah dilakukan dengan menggunakan sistem tugas anggota kelompok, (5) pemasaran ikan dapat dilakukan sesuai dengan pesanan dan permintaan, dan (6) lebih kecil membutuhkan modal usaha, karena dilakukan dengan urunan dari semua anggota kelompok, sehingga terasa lebih ringan.

$$
\text { Saat ini di Desa Abang Batu }
$$

Dinding terdapat 7 (tujuh) kelompok nelayan ikan air tawar yang menggunakan sistem kramba untuk mebudidayakan ikan. Masing-masing kelompok ada yang beranggotakan 5 sampai 7 orang. Setiap kelompok memiliki satu buah kramba yang luasnya bisa mengcapai 1000 m2. Untuk dapat menjadi anggota kelompok masingmasing anggota kelompok diwajibkan membayar uang pangkal yang digunakan untuk membuat kramba, membeli bibit dan membeli pakan ikan. Sedangkan proses perawatan dilakukan dengan sistem 
pembagian tugas dan tangungjawab yang diberikan pada masing-masing anggota kelompok. Setiap anggota kelompok akan mendapatkan tugas yang sama untuk setiap siklusnya, mulai dari memberikan pakan ikan, melakukan perawatan ikan, memanen ikan dan menjual ikan hasil kramba. Setiap sebulan sekali, kelompok nelayan ikan air tawar ini mengadakan sangkep (musyawarah) untuk membicarakan berbagai hal yang berkaitan dengan persoalan nelayan, khususnya ikan air tawar yang dipelihara. Pembudidayaan ikan kramba dengan sistem kelompok ini sangat efektif dalam membudidayakan ikan air tawah di wilayah Danau Batur. Walapun demikian sampai saat ini terdapat berbagai permasalahan berkaitan dengan budidaya ikan air tawar dengan model kramba ini, yaitu:

1) Masalah pembibiatan, yaitu sulit mencari bibit ikan yang memiliki kualitas bagus. Bibit ikan yang memiliki kualitas baik biasanya sangat mudah berkembang dan besar. Sementara sampai saat ini para nelayan ikan air tawar dengan model kramba di Desa Abang Batu Dinding hanya mengandalkan bibit yang dibudidayakan sendiri, tanpa melalui proses uji coba kualitas bibit yang memadai. Akibatnya ikan yang dipelihara dalam kramba sulit besar dan memakan biaya perawatan dan pakan yang besar.

2) Masalah perawatan, yaitu proses pemberian pakan dan perawatan ikan kramba yang terdapat ditengah danau membutuhkan sarana transportasi yang memadai. Namun saat ini para nelayan hanya menggunakan perahu sampan untuk memberikan pakan dan merawat ikannya. Kondisi ini sering menyebabkan keterlabatan pada saat waktu pemberian pakan. Demikian juga dengan proses penanganan berbagai penyakit yang dialami oleh ikan, sering terlambat mendapatkan penanganan karena sarana yang digunakan kurang memadai.

3) Masalah pakan ikan, yaitu tingginya harga pakan ikan yang dihasilkan oleh pabrik. Tingginya harga pakan ikan sering menimbulkan persolan berkaitan dengan modal usaha dan harga ikan.
Modal usaha menjadi lebih tinggi yang berimplikasi pada peningkatan harga ikan, sementara ikan sudah dipesan terlebih diawal, sehingga menyulitkan kelompok nelayan ikan kramba. Bahkan tidak jarang para kelompok nelayan merugi akibat peningkatan harga pakan ikan.

4) Pemasaran dan pengemasan produk atau packing. Hasil ikan kramba yang dibudidayakan oleh kelompok nelayan ikan air tawar di Desa Abang Batu Dinding masih dijual dengan cara tradisional dengan membawa kepasarpasar yang ada di sekitar wilayah Kecamatan Kintamani atau menjualnya kepada pengepul yang menjualnya di beberapa restoran yang ada di daerah wisata Gunung Batur. Ikan yang dihasilkan dijual begitu saja setelah dipanen tanpa pengemasan yang memadai, sehingga kurang menarik dan harga jualnyapun sangat rendah.

5) Pengolahan pasca panen. Ketika masa panen dengan kelompok kramba lain bersamaan, sering terjadi kelebihan produk yang menyebabkan rendahnya harga jual ikan. Sementara para nelayan ikan air tawar di Desa Abang Batu Dinding sampai saat ini belum memiliki kemampuan dalam mengelola ikan pasca panen. Bahkan dengan melimpahnya ikan yang bisa dihasilkan oleh kelompok nelayan ikan kramba di Desa Abang Batu Dinding semestinya memiliki kemampuan untuk melakukan pengolahan ikan pasca panen, sehingga harga jual hasil kramba dapat menjadi stabil dan tidak merugikan kelompok nelayan. Berdasarkan pada analisis kebutuhan dan perumusan masalah prioritas yang dilakukan bersama-sama dengan kelompok nelayan ikan kramba di Desa Abang Batu Dinding disepakati permasalaha yang akan dicarikan solusinya dalam program iptek bagi masyarakat ini adalah yang berkaitan dengan "packing dan pengolahan ikan pasca panen". Persoalan ini dinilai urgen oleh para nelayan, mengingat pengemasan produk dan pengolahan pasca panen akan dapat meningkatkan nilai jual produks yang dihasilkan oleh para nelayan ikan kramba di Desa Abang 
Batu Dinding Kintamani.

\section{METODE PELAKSANAAN}

\section{Mengingat kompleksnya}

permasalahan yang dihadapi oleh mitra sebagai mana yang digambarkan di atas, maka disepakati beberapa persoalan prioritas yang akan diatasi melalui kegiatan iptek bagi masyarakat ini, yaitu masalah pengemasan produks dan masalah pengolahan ikan kramba pasca panen. Berdasarkan pada permasalahan prioritas tersebut, maka solusi yang ditawarkan melalui iptek bagi masyarakat (IbM) ini adalah: 1. Pelatihan packing. Pelatihan packing akan dierikan oleh pakar dari Dinas Perindustrian dan Perdagangan Kabupaten Bangli. Pengemasan produk sangat penting untuk meningkatkan nilai ekonomis dan menambah nilai estetik produk yang dihasilkan. Salah satu kelemahan produk hasil/buatan dalam negeri adalah pada kemasannya, sehingga menjadi kurang menarik dan kalah saing dengan produk negara lain. Padahal dilihat dari kualitas produk antara hasil ikan kramba dalam negeri dengan luar negeri tidak jauh berbeda. Bahkan produk yang dihasilkan dari ikan di Indonesia lebih "alami" d en gan pr oses pengerjaan yang bersifat tradisional. Dengan pengemasan yang baik produk ikan kramba yang dihasilkan kelompok nelayan ikan kramba Desa Abang Batu Dinding akan memiliki daya saing dan lebih menarik, sehingga secara otomatis akan meningkatkan harga jual yang secara langsung meningkatkan penghasilan para nelayan ikan kramba di Desa Abang Batu Dinding. 2. Pelatihan dan pendampingan pengolah produk pasca panen. Pelatihan ini akan difokuskan pada dua aspek, yaitu (1) apek IPTEK, (2) aspek manajemen. Apek ilmu pengetahuan dan teknologi diberikan berkaitan dengan proses produksi ikan, cara pengemasan produks dan pengolahan pasca panen. Sedangkan untuk aspek manajemen menyangkut manajemen produksi, manajemen kinerja dan manajemen pemasaran produks. Pelatihan dan pendamping pengolahan produk pasca panen akan diberikan oleh pakar Pendidikan Kesejahteraan Keluarga (PKK) Undiksha (Dosen Jurusan Pendidikan Kesejahteraan Keluarga Undiksha) dan untuk aspek manajemen akan diberikan oleh pakar Pendidikan Ekonomi Undiksha. Pelatihan dan pendamping pengolahan produk pasca panen akan dimulai dengan memberikan materi tentang strategi pengolahan produk pasca panen, pelatihan pembuatan krupuk ikan air tawar khas Kintamani. Selama ini para nelayan hanya melakukan penjualan ikan setalah dipanen, sehingga dimasa-masa musim panen yang bersamaan terjadi akan terjada kelebihan produk, sehingga harga jualnya menjadi rendah. Hal ini menyebabkan para nelayan merugi, terlebih harga pakan dan perawatan yang semakin tinggi. Untuk mengukur tingkat keberhasilan kegiatan yang telah dilakukan, maka akan dilakukan evaluasi minimal 3 (tiga) kali, yaitu evaluasi proses, evaluasi akhir, dan evaluasi tindak lanjut. Kegiatan evaluasi ini akan melibatkan tutor/pakar dari Undiksha Singaraja dan Dinas Kerajinan dan Perindustrian Kabupaten Bangli. Kriteria dan indikator pencapaian tujuan dan tolak ukur yang digunakan untuk menjastifikasi tingkat keberhasilan kegiatan dapat diuraikan pada tabel berikut :

Tabel 1 Kriteria Keberhasilan Pelatihan Kelompok Nelayan Ikan Kramba

\begin{tabular}{|l|l|l|l|l|l|}
\hline No & \multicolumn{1}{|c|}{ Jenis Data } & $\begin{array}{l}\text { Sumber } \\
\text { Data }\end{array}$ & \multicolumn{1}{|c|}{ Indikator } & Kriteria Keberhasilan & Instrumen \\
\hline 1 & $\begin{array}{l}\text { Pengetahuan } \\
\text { dan ketrampilan } \\
\text { melakukan } \\
\text { pengemasan } \\
\text { produk ikan } \\
\text { kramba }\end{array}$ & $\begin{array}{l}\text { Kelompok } \\
\text { nelayan } \\
\text { ikan } \\
\text { kramba }\end{array}$ & $\begin{array}{l}\text { Pengetahuan dan } \\
\text { keterampilan } \\
\text { kelompok nelayan } \\
\text { ikan kramba }\end{array}$ & $\begin{array}{l}\text { Terjadi perubahan } \\
\text { pengetahuan dan } \\
\text { ketrampilan kelompok } \\
\text { nelayan dalam } \\
\text { mengemas produk ikan } \\
\text { kramba yang dihasilkan }\end{array}$ & $\begin{array}{l}\text { Pedoman } \\
\text { Observasi } \\
\text { dan } \\
\text { Wawancara }\end{array}$ \\
\hline 2 & $\begin{array}{l}\text { Pengetahuan } \\
\text { dan ketrampilan } \\
\text { melakukan } \\
\text { pengolahan } \\
\text { produk ikan }\end{array}$ & $\begin{array}{l}\text { Kelompok } \\
\text { nelayan } \\
\text { ikan } \\
\text { kramba }\end{array}$ & $\begin{array}{l}\text { Pengetahuan dan } \\
\text { keterampilan } \\
\text { kelompok nelayan } \\
\text { ikan kramba }\end{array}$ & $\begin{array}{l}\text { Terjadi perubahan } \\
\text { pengetahuan dan } \\
\text { ketrampilan melakukan } \\
\text { pengolahan produk ikan } \\
\text { kramba pasca panen }\end{array}$ & $\begin{array}{l}\text { Pedoman } \\
\text { Observasi } \\
\text { dan } \\
\text { Wawancara }\end{array}$ \\
\hline
\end{tabular}




\begin{tabular}{|c|c|c|c|c|c|}
\hline No & Jenis Data & $\begin{array}{l}\text { Sumber } \\
\text { Data }\end{array}$ & Indikator & Kriteria Keberhasilan & Instrumen \\
\hline & $\begin{array}{l}\text { kramba pasca } \\
\text { panen }\end{array}$ & & & & \\
\hline 3 & $\begin{array}{l}\text { Pengetahuan } \\
\text { dan keterampilan } \\
\text { mengembangkan } \\
\text { IPTEK packing } \\
\text { dan pengolahan } \\
\text { pasca panen }\end{array}$ & $\begin{array}{l}\text { Kelompok } \\
\text { nelayan } \\
\text { ikan } \\
\text { kramba }\end{array}$ & $\begin{array}{l}\text { Pengetahuan dan } \\
\text { keterampilan } \\
\text { kelompok nelayan } \\
\text { ikan kramba }\end{array}$ & $\begin{array}{l}\text { Terjadi perubahan } \\
\text { pengetahuan dan } \\
\text { keterampilan } \\
\text { mengembangkan IPTEK } \\
\text { packing dan pengolahan } \\
\text { pasca panen }\end{array}$ & $\begin{array}{l}\text { Pedoman } \\
\text { Observasi } \\
\text { dan } \\
\text { Wawancara }\end{array}$ \\
\hline 4 & $\begin{array}{l}\text { Pengetahuan } \\
\text { dan keterampilan } \\
\text { manajemen } \\
\text { produksi, kinerja, } \\
\text { dan manajemen } \\
\text { pemasaran }\end{array}$ & $\begin{array}{l}\text { Kelompok } \\
\text { nelayan } \\
\text { ikan } \\
\text { kramba }\end{array}$ & $\begin{array}{l}\text { Pengetahuan dan } \\
\text { keterampilan } \\
\text { kelompok nelayan } \\
\text { ikan kramba }\end{array}$ & $\begin{array}{l}\text { Terjadi perubahan } \\
\text { pengetahuan dan } \\
\text { keterampilan manajemen } \\
\text { produksi, kinerja, dan } \\
\text { manajemen pemasaran }\end{array}$ & $\begin{array}{l}\text { Pedoman } \\
\text { Observasi } \\
\text { dan } \\
\text { Wawancara }\end{array}$ \\
\hline
\end{tabular}

Pada kegiatan pelatihan IbM ini kelompok nelayan ikan kramba di Desa Abang Batu Dinding Kecamatan Kintamani akan dilibatkan dari awal sampai akhir kegiatan. Kelompok nelayan ikan kramba akan dilibatkan dalam merencanakan program, penjadwalan kegiatan, penyediaan bahan, khususnya ikan kramba yang dihasilkan, ikut serta dalam pelatihan sampai pada tahap uji coba produk pelatihan. Pelibatan kelompok nelayan ikan kramba secara penuh ini diharapkan dapat memberikan seperangkat pengatahun dan keterampilan yang lengkap kepada para nelayan ikan kramba dalam melakukan pengemasan terhadap produk ikan kramba yang dihasilkan dan melakukan pengolahan pasca panen serta cara pengembangannya.

\section{HASIL YANG DICAPAI \\ 1) Koordinasi Kegiatan P2M}

Untuk

menyukseskan

penyelenggaraan program tidak terlepas dengan prosedur birokrasi yang dilakukan oleh tim pelaksana dari Universitas Pendidikan Ganesha (UNDIKSHA). Langkah program yang tim pelaksana rancang diantaranya meliputi:

koordinasi, (2) pelaksanan, dan (3) evaluasi. Langkah awal yang tim pelaksana lakukan adalah rapat koordinasi tahap awal untuk merancang pertemuan dan koordinasi,dilanjutkan dengan rapat untuk merancang pelaksanaan kegiatan tahap awal. Setelah kesepakatan waktu ditentukan untuk melakukan koordinasi dengan aparatur Pemerintah Desa Abang Batu Dinding Kintamani, Kecamatan Kubu.
Proses administrasi yang tim pelaksana program harus penuhi yaitu meliputi, secara bertim sebelumnya berkoordinasi dengan Lembaga Pengabdian Masyarakat (LPM) untuk meminta surat pengantar kegiatan pengabdian dan surat perjalanan dinas resmi yang substansinya memuat Permohonan untuk Mengadakan Pengabdian Pada Masyarakat sesuai dengan rencana kegiatan Pengabdian Pada Masyarakat (P2M) dengan materi 1) Pelatihan melakukan pengemasan produk ikan kramba, 2) melakukan pengolahan produk ikan kramba pasca panen, dan 3) mengembangkan IPTEK packing dan pengolahan pasca panen.

Alur birokrasi pelaksanaan program dengan mendatangi langsung desa tujuan P2M dan bersilaturahmi dengan aparatur desa setempat. Adapun hasil koodinasi tim dengan birokrasi Pemerintahan Desa Abang Batu Dinding Kintamani, diantaranya: kesepakatan jadwal kegiatan, tempat penyelenggaraan, agenda kegiatan, termasuk pedataan peserta pelatihan dari masing-masing dusun di Desa Abang Batu Dinding Kintamani dikoordinir oleh I Wayan Widiana, S.Pd., M.Pd dan I Made Satyawan, S.Pd.,M.Pd. dan dibantu oleh Ida Bagus Sidartha Manuaba, SE peternak ikanmujair kintamani.

Program yang kami rancang dan usulkan untuk diselenggarakan di Desa Abang Batu Dinding Kintamani memperoleh apresiasi yang sangat luar biasa dari Pemerintah Desa setempat beserta jajarannya. Mengingat baru pertama kali Desa Abang Batu Dinding 
Kintamani disasar kegiatan pengabdian dengan melibatkan warga masyarakat untuk mampu diberdayakan melalui kegiatan sosialisasi dan pelatihan dari pihak LPM Undiksha. Secara langsung dengan penuh penghargaan dan penghormatan Kepala Desa beserta staf menyambut kami dengan tangan terbuka dan mengucapkan terima kasih kepada LPM Undiksha karena sudah bersedia memfasilitasi warga Desa Abang Batu Dinding Kintamani dengan penerjunan staf ahli yang berkompeten melalui penyelenggaraan kegiatan P2M. Harapan dari output program P2M yang tim pelaksana selenggarakan dan dharmakan kepada warga masyarakat yang dalam hal ini diwakili oleh masyarakat Desa Abang Batu Dinding Kintamani Desa Abang Batu Dinding Kintamani Kecamatan Kubu kabupaten Karangasem.

\section{2) Pendidikan dan Pelatihan Pengolahan Produk Ikan Kramba Pasca Panen}

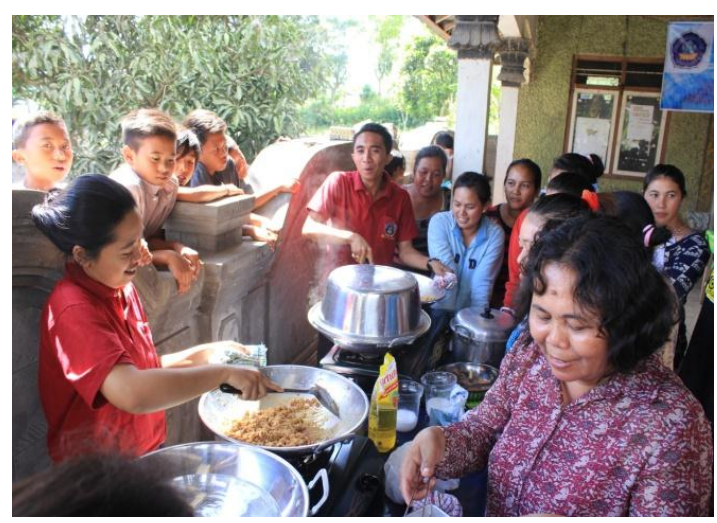

Gambar 1. Proses Pembuatan Abon Mujair

Pada pelatihan ini materi disampaikan oleh I Wayan Widiana, S.Pd., M.Pd, beliau banyak menyampaikan materi tentang berbagai macam olahan ikan mujair. Pelatihan ini dilaksanakan pada tanggal 10 Juni 2015 bertempat di baai desa Abang Batu Dinding Kintamani yang diikuti oleh 30 orang peserta. Peserta sangat antusias mengikutinya. Pendidikan dan pelatihan dilaksanakan melalui metode praktek langsung pengolahan bahan baku, bambu, dan sebagainya sehingga siap menjadi bahan dasar produk kreatif yang selanjutnya digunakan pada usaha kelompok. Beberapa olahan yang dipraktikan adalah bakso ikan mujair, abon ikan mujair, krupuk mujair dan mujair goreng dan bakar dengan aneka bumbu manis, pedas, asam, dan lain-lain. Dalam pelaksanaan diklat ini tidak ditemukan kendala yang berarti karena respon yang sangat bagus dari masyarakat yang mengikuti pelaksanaan kegiatan ini.

Pelaksanaan pelatihan berjalan dengan lancar dan baik terlihat dari besarnya perhatian dari anggota kelompok dalam menyimak serta memperhatikan materi-materi yang disampaikan sekaligus praktek langsung meracik dan mengolah adonan. Hasil pelatihan menunjukkan bahwa dari 30 orang yang ikut pelatihan 25 orang $(83,33 \%)$ masuk dalam kategori sangat mengetahui dan terampil dalam pengolahan produk ikan kramba pasca panen, 2 orang $(2,66)$ termasuk dalam kategori kategori mengetahui dan terampil dalam pengolahan produk ikan kramba pasca panen, dan 5 orang $(16,66)$ termasuk dalam kategori cukup mengetahui dan terampil dalam pengolahan produk ikan kramba pasca panen.

\section{3) Diklat Mengembangkan IPTEK Packing Hasil Pengolahan Ikan Mujair}

Kegiatan ini terlaksana tanggal 11 Juni sampai dengan 13 Juni 2014 dengan pen dampingan dari tim pelaksana P2M. Oerientasi kegiatan pengembangan IPTEK packing hasil pengolahan ikan mujair bertujuan untuk meningkatkan nilai jual hasil olahan mujair yang sudah dibuat oleh masyarakat menjadi lebih tertata, lebih terlihat bersih dan rapi sehingga layak untuk dijual di pasar-pasar. Agenda kegiatan berupa pengemasan abon, bakso, dan krupuk ikan dengan plastik, dan pemberian lebel. Plastik yang digunakan dipilih sesuai dengan daya tahan makanan. Salah satu alat yang digunakan adalah mesin hand sealer. Mesin ini digunakan untuk mengemas abon, bakso, dan krupuk ikan yang dibungkus dengan kemasan plastik. Pengoperasian mesin hand impulse sealer dilakukan menggunakan tangan secara manual dan sangat mudah. Anda cukup meletakan plastik kemasan diantara hand sealer tersebut, lalu di tekan layaknya mesin press. Dengan 
menggunakan mesin pengemas hand sealer, makanan Anda dapat bertahan

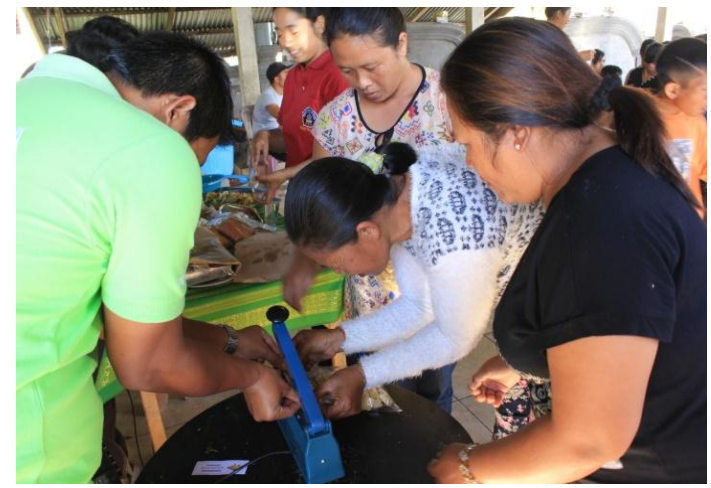

lebih lama karena tersimpan rapat dalam plastik.

Gambar 2. Proses Packing Hasil Pengolahan Ikan Mujair

Pelaksanaan pelatihan berjalan dengan lancar $\mathrm{d}$ an baik terlihat dari besarnya perhatian dari anggota kelompok dalam menyimak serta memperhatikan materimateri yang disampaikan sekaligus praktek langsung meracik dan mengolah adonan. Hasil pelatihan menunjukkan bahwa dari 30 orang yang ikut pelatihan 20 orang $(66,67 \%)$ masuk dalam kategori sangat mengetahui dan terampil dalam mengembangkan IPTEK packing dan pengolahan pasca panen, $5(16,66)$ orang termasuk dalam kategori kategori mengetahui dan terampil dalam mengembangkan IPTEK packing dan pengolahan pasca panen, dan 5 orang $(16,66)$ termasuk dalam kategori cukup mengetahui dan terampil dalam mengembangkan IPTEK packing dan pengolahan pasca panen.

\section{4) Pelatihan Manajemen Manajemen Pemasaran}

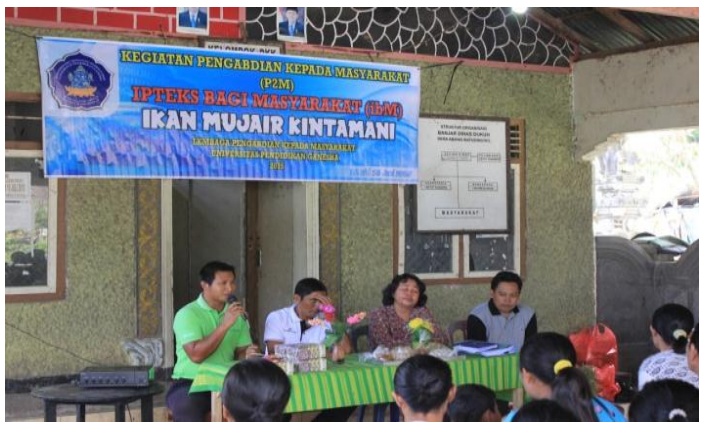

Gambar 3. ProsesPelatihan manajemen Pemasaran

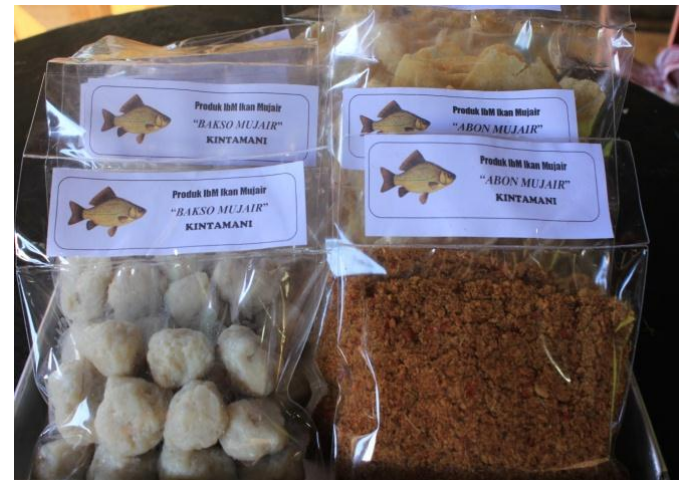

Kegiatan ini akan dilaksanakan pada tanggal 19-20 Agustus 2015 oleh instruktur tamu dari Jurusan D3 Akuntansi, yaitu Ibu I Gusti Ayu Purnamawati, SE., M.Si., Ak. Tujuannya untuk melakukan pendampingan tentang manajemen usaha dengan pengelolaan usaha kreatif mandiri secara berkelompok oleh masyarakat Desa Abang Batu Dinding Kintamani sekaligus membuka peluang baru berupa usaha kreatif yang merupakan bentuk UBK rintisan dengan pengolahan hasil tangkapan ikan.

Pelaksanaan pelatihan berjalan dengan lancar dan baik terlihat dari besarnya perhatian dari anggota kelompok dalam menyimak serta memperhatikan materi-materi yang disampaikan. Hasil pelatihan menunjukkan bahwa dari 30 orang yang ikut pelatihan 20 orang $(66,67 \%)$ masuk dalam kategori sangat memahami manajemen pemsaran dengan baik, $5(16,66)$ orang termasuk dalam kategori memahami manajemen pemsaran dengan baik, dan 5 orang $(16,66)$ termasuk dalam kategori cukup manajemen pemsaran dengan baik.

Sesuai hasil kesepakatan dengan peserta pelatihan, pendampingan selanjutnya adalah pengurusan surat ijin usaha perdagangan (SIUP) yang dalam hal ini akan digunakan nama perorangan sehingga usaha dagangnya kedepan berkekuatan hukum. Hal ini juga dilakukan untuk melindungi produk-produk kreatif yang akan dihasilkan oleh kelompok 
dikemudian hari. Prosedur dan tata cara pengurusan ijin juga dilatihkan kepada masyarakat Desa Abang Batu Dinding Kintamani untuk memberikan bekal tentang pengurusan ijin usaha baik yang sifatnya individu maupun kelompok. Pengurusan ijin penting karena nantinya Wanita Nelayan Desa Abang Batu Dinding Kintamani dapat menggunakan SIUP yang dimiliki sebagai agunan simpan pinjam di LPD maupun BRI terdekat di tingkat Kecamatan. Kemudian tahap selanjutnya adalah pemandirian dan pendampingan selama masyarakat membuka usaha mandiri. Pemandirian dilakukan dengan memberikan materi motivasi dan menjalin kerjasama untuk mencari modal kerja.

\section{PEMBAHASAN}

Setelah diberikan pelatihan oleh tim pelaksana dari Undiksha Singaraja, masyarakat Desa Abang Batu Dinding Kintamani Kecamatan Kubu dapat memahami dengan jelas materi pelatihan mengenai tata boga dalam hal mengolahan hasil tangkapan ikan mujair yang semula keterampilan mengolahnya tidak dikuasai dan sekarang menjadi dikuasai dapat dipraktekannya menjadi beragam jenis olahan produk hasil karya olahan kuliner yang telah dilakukan pendampingan dari pihak tim pelaksana IbM Mujair Desa Abang Batu Dinding Kintamani. Diklat pengelolaan ikan mujair ini bertujuan untuk menunjang tingkat pengetahuan dan wawasan masyarakat tentang pemberdayaan kawasan pesisir secara tepat guna.

Keunggulan yang dapat dilihat dali pelaksanaan program, bahwa berdasarkan hasil evaluasi tidak lanjut juga terekam, beberapa manfaat praktis yang diperoleh oleh masyarakat Desa Abang Batu Dinding Kintamani melalui Pelatihan Tata Boga Pengelolaan Ikan Mujair, yaitu: (1) mereka mendapatkan informasi yang jelas dan utuh mengenai hakekat pemberdayaan masyarakat dari segi pengetahuan dan keterampilan, bermakna untuk penciptaan lapangan pekerjaan baru yang sifatnya inovatif dari pengolahan ikan mujair; (2) masyarakat Desa Abang Batu Dinding Kintamani yang menjadi peserta pelatihan memperoleh gambaran yang jelas mengenai langkah pengembangan iklim usaha dengan memanfaatkan komoditas hasil tangkapan ikan secara swadaya; (3) peserta pelatihan juga mendapatkan gambaran yang jelas dan utuh tentang manfaat hasil tangkapan ikan apabila dikelola dengan baik akan mendatangkan nilai finansial apabila telah diolah menjadi aneka olahan kuliner ikan mujair sebagai menu handalan.

Keseluruhan proses transfer iptek ini dilaksanakan dengan pola pelatihan dan pendampingan terhadap masyarakat Desa Abang Batu Dinding Kintamani yang meliputi: Tata Boga, dan Tata Cara Pengurusan ljin Usaha. Pelatihan dengan pendampingan terhadap proses produksi, dan tata cara pengurusan ijin usaha, sehingga diharapkan kegiatan P2M yang diselenggarakan dapat menyasar penguasaan pengetahuan dan keterampilan Kelompok masyarakat Desa Abang Batu Dinding Kintamani secara berkesinambungan.

\section{Kendala dan Tindak Lanjut yang harus Dilakukan}

Kendala pelaksanaan program adalah sulitnya meminid waktu untuk pencapaian kesepakatan pelaksanaan kegiatan, karena umumnya peserta latihan terbentur dengan rutinitas pekerjaan harian yang menunjang perekonomian keluarga, maupun pelaksanaan kegiatan ritual adatistiadat yang lumayan padat di Desa Abang Batu Dinding Kintamani dalam kaitannya dengan paruman desa adat untuk penyelenggaraan ritual keagamaan sebagaimana layaknya masyarakat Hindu Bali pada umumnya. Jadi, untuk bisa mengkoordinir warga perlu koordinasi intensif dengan pihak kesra dan segenap jajarannya. Berkaitan dengan pengkondisian peserta program, walaupun dijumpai kendala masalah waktu selama tim pelaksana program mampu mengatasinya dengan melakukan koordinasi secara intensif dengan Kepala Desa Abang Batu Dinding Kintamani, staf Kesra Desa Abang Batu Dinding Kintamani, dan segenap jajaran terkait masyarakat Desa Abang Batu Dinding Kintamani. Program ini masih berlangsung dan masih banyak terdapat kekuarangankekurangan yang ada dalam pengabdian ini. Terutama untuk mengukur 
keberhasilan pengimplementasian dari kurikulum yang sudah dirancang.

\section{PENUTUP}

Kesimpulan yang dapat diperoleh dari pelaksanaan program pengabdian ini adalah:

1. Tingkat partisipasi yang tinggi dari mitra program pengabdian kepada masyarakat memberikan dampak positif bagi pelaksanaan program, terlihat dari kehadiran peserta yang tanpa ijin, dan dukungan dari kepala desa.

2. Hasil pelatihan menunjukkan bahwa dari 30 orang yang ikut pelatihan 25 orang $(83,33 \%)$ masuk dalam kategori sangat mengetahui dan terampil dalam pengolahan produk ikan kramba pasca panen, 2 orang $(2,66)$ termasuk dalam kategori kategori mengetahui dan terampil dalam pengolahan produk ikan kramba pasca panen, dan 5 orang $(16,66)$ termasuk dalam kategori cukup mengetahui dan terampil dalam pengolahan produk ikan kramba pasca panen.

3. Hasil pelatihan menunjukkan bahwa dari 30 orang yang ikut pelatihan 20 orang $(66,67 \%)$ masuk dalam kategori sangat mengetahui dan terampil dalam mengembangkan IPTEK packing dan pengolahan pasca panen, $5(16,66)$ orang termasuk dalam kategori kategori mengetahui dan terampil dalam mengembangkan IPTEK packing dan pengolahan pasca panen, dan 5 orang $(16,66)$ termasuk dalam kategori cukup mengetahui dan terampil dalam mengembangkan IPTEK packing dan pengolahan pasca panen.

4. Kendala pelaksanaan program adalah sulitnya meminid waktu untuk pencapaian kesepakatan pelaksanaan kegiatan, karena umumnya peserta latihan terbentur dengan rutinitas pekerjaan harian yang menunjang perekonomian keluarga, maupun pelaksanaan kegiatan ritual adatistiadat yang lumayan padat di Desa Abang Batu Dinding Kintamani dalam kaitannya dengan paruman desa adat untuk penyelenggaraan ritual keagamaan sebagaimana layaknya masyarakat Hindu Bali pada umumnya.

\section{DAFTAR PUSTAKA}

Dasman, Raymon. 1980. Prinsip Ekologi Untuk Pembangunan, Terjemahan Idjah Soemarwoto. Jakarta: Gramedia.

Gerungan. 1988. Psikologi Sosial. Bandung: Unesco.

Karama dan Abdurrachman. 1995. Kebijakan Nasional dalam Penanganan Lahan Kritis di Indonesia. Yogyakarta: BPTP Prosiding Seminar Rekayasa Teknologi Konservasi.

Kurana. 2008. Sukses Mengembangkan Wirausaha. Jakarta: Grsindo.

Kurniasih Dian. 2006. Pengaruh Daya Dukung Lahan dan Faktor Sosial Ekonomi terhadap Perilaku Petani dalam Konservasi Lahan Pertanian di Kabupaten Kulon Progo. Yogyakarta: Program Studi Ekonomi Pertanian, Jurusan IImu-IImu Pertanian, UGM.

Muhadjir, N. 1993. Kepemimpinan Adopsi Inovasi untuk Pengembangan Masyarakat. Yogyakarta: Rake Press.

Negara Republik Indonesia. UndangUndang Nomor 5 Tahun 1999 tentang Larangan Praktek Monopoli dan Persaingan Usaha Tidak Sehat. Lembaran Negara Nomor 33, TLN RI Nomor 3817.

Pemerintah Kabupaten Karangasem. Data Statistik Desa Tianyar Tahun 2011. Karangasem: Tianyar.

Suhardjo. 1988. Peranan Kelembagaan dalam Hubungannya dengan Komersialisasi Usahatani dan Distribusi Pendapatan Wilayah Kabupaten Banjar Negara Jawa Tengah. Disertasi (tidak dipublikasikan). Yogyakarta: UGM.

Soemarwoto, Otto. 2001. Ekologi, Lingkungan Hidup, dan Pembangunan. Jakarta: Penerbit Djambatan. 